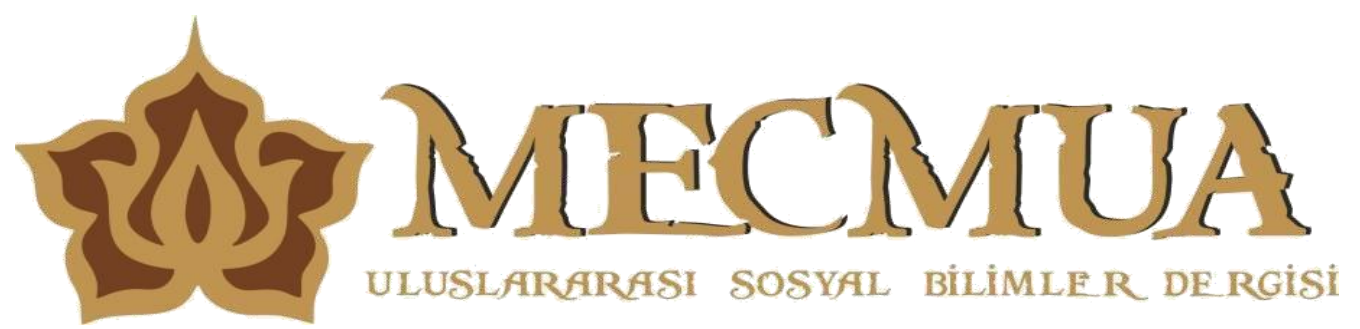

Mecmua Uluslararasi Sosyal Bilimler Dergisi [International Journal Of Social Sciences] Uluslararası Hakemli E-Dergi/ Referee International E-Journal Yil: 6, Sayı: 11, ISSN:2587-1811 Yayımlanma Tarihi: 30.03.2021

Türkiye Cumhuriyeti Tarihi- III (19391945), Milli Şef Dönemi
The History of the Republic of Turkey III (1939-1945), Period of the National Chef

\title{
Gürdal Çetinkaya
}

D Ankara Üniversitesi, Türk İnkılap Tarihi Enstitüsü, Doktora Öğrencisi, Ankara, Türkiye. gurdal_45@hotmail.com

\section{Makale Bilgisi / Article Information}

Makale Türü: Yayın Değerlendirme

DOI: mecmua. 830486

Yükleme Tarihi: 24.11.2020

Kabul Tarihi: 09.01.2021

Yayımlanma Tarihi: 30.03 .2021

Sayı: 11

Sayfa: 535-539
Article Information: Publication Review

DOI: mecmua. 830486

Received Date: 24.11.2020

Accepted Date: 09.01.2021

Date Published: 30.03.2021

Volume: 11

Sayfa: $535-539$

\section{Atıf / Citation}

ÇETINKAYA G. (2021). Türkiye Cumhuriyeti Tarihi - III (1939- 1945), Milli Şef Dönemi. MECMUA - Uluslararast Sosyal Bilimler Dergisi ISSN: 2587-1811 Y11: 6, Say1: 11, Sayfa: 535539

ÇETINKAYA G. (2021). The History of the Republic Of Turkey - III (1939-1945), Period of the National Chef. MECMUA - International Journal Of Social Sciences ISSN: 2587-1811 Year: 6, Volume: 11, Page: 535-539 


\section{TÜRKIYYE CUMHURIYETİ TARİHI - III (1939- 1945), MILLII ŞEF DÖNEMI}

(Mahmut Goloğlu, Türkiye İş Bankası Kültür Yayınları, İstanbul, 2012, S. 478, ISBN: 978-605-360-580-5)

\section{MAHMUT GOLOḠLU}

Türkiye Cumhuriyeti Tarihi-III 1939-1945

\section{MiLLi SEF DÖNEMi}

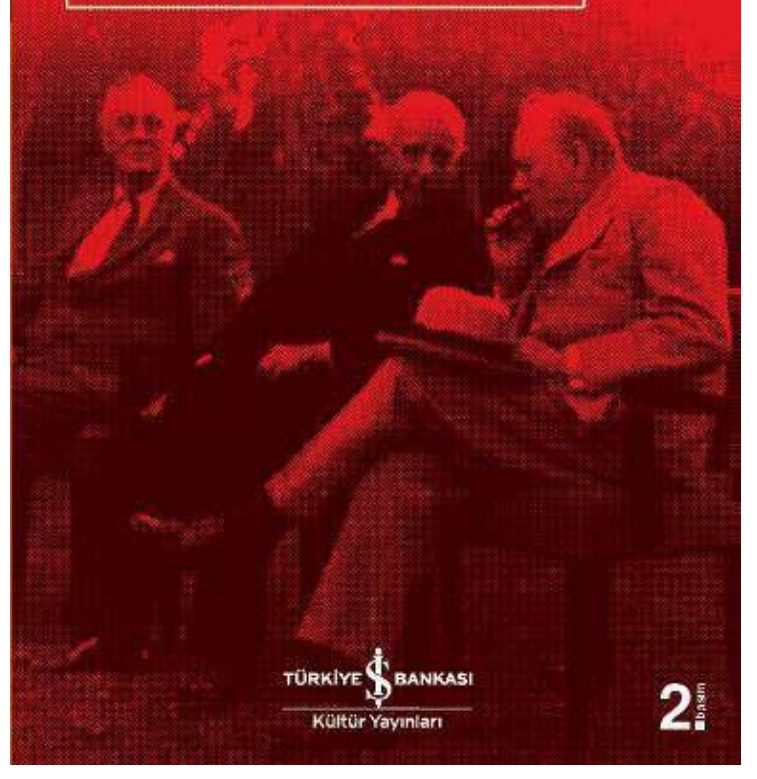

Mustafa Kemal Atatürk'ün 10 Kasim 1938 yilında vefat etmesinden sonra İsmet İnönü Türkiye Cumhuriyeti Devleti'nin ikinci Cumhurbaşkanı olmuştur. Kendisine "Milli Şef" unvanı verilmiştir. İsmet İnönü’nün 1950 y1lına kadar süren Cumhurbaşkanlığı döneminde 1939- 1945 y1lları arasında meydana gelen İkinci Dünya Savaşı ülkemizin içinde bulunduğu zor dönemlerden birisini oluşturmuştur. İkinci Dünya Savaşı ülkemizin aktif olarak katılmadığı ama etkilerini derinden hissettiği bir savaş olmuştur. Meydana gelen savaş ülkemizde siyasi, sosyal, ekonomik ve kültürel olarak etkilerini göstermiştir. Özellikle sosyal ve ekonomik boyutları bakımından etkisi oldukça fazla hissedilmiștir. Dönemin Cumhurbaşkanı İsmet İnönü'nün uygulamış olduğu "Denge Politikası" sayesinde ülkemiz savaşın belki de daha yıkıcı olabilecek boyutlarını yaşamaktan kurtulmuştur.

Eser Türkiye'nin İkinci Dünya Savaşı yıllarını kapsayan (1939- 1945) dönemini incelemektedir. Eserde Türkiye'nin İkinci Dünya Savaşı'nın başladığı tarih olan 1939'dan 1945'te sona ermesine kadar olan dönemdeki iç ve dış politikası hakkında meydana gelen önemli gelişmeleri ele almaktadır. İncelemesini yapacağım eser İkinci Dünya Savaşını Mahmut Goloğlu tarafından kaleme alınarak Türkiye İş Bankası Kültür Yayınları tarafından yayımlanmıştır.

Eserin ilk bölümü 1939 yılında meydana gelen olaylara değinmektedir. Refik Saydam Hükümeti hakkında genel bilgiler verilerek konuya giriş yapılmıştır. 
Hükümet hakkındaki değerlendirmelerden sonra Altıncı T.B.M.M. Meclisi hakkında kapsamlı bir bilgi verilerek okuyucuların genel bir fikir sahibi olması amaçlanmıştır. Cumhuriyet Halk Partisi’nin kurmuş olduğu müstakil grup hakkında yazar okuyuculara bilgi verdikten sonra savaş öncesindeki Türkiye'nin Dış İlişkilerine değinmiştir. Yine İkinci Dünya Savaşı öncesi ülkemiz açısından hayati bir öneme sahip olan Hatay'nn Anavatana katılması konusunda önemli bilgiler vermiştir. Tüm bu gelişmelerin ardından ise İkinci Dünya Savaşı'nın başlaması hakkındaki konuya giriş yapılmıştır. Yazar ayrıca Türk-Rus İlişkileri hakkında da okuyucuyu bilgilendirmiştir. Yazarın burada sadece Türk-Rus ilişkilerine değinerek diğer büyük devletlerle olan ilişkilerimize değinmemesi konunun eksik anlaşılması yönünden önem taşımaktadır. Yazarın bu bölümde diğer büyük devletlerle olan ilişkilerimiz konusunda da bilgi vermesi daha uygun olacaktır. Yazar Türk-Rus ilişkilerine değindikten sonra 1939 yılında imzalanan Türk-İngiliz-Fransız üçlü yardım antlaşması konusu ele almıştır. Bölümün sonunda ise daha savaşın başlarında ülkemizi derinden etkileyen 1939 Erzincan Depremi konusuna değinilmiştir.

Eserin ikinci bölümü 1940 yılında meydana gelen olaylardan oluşmaktadır. Savaş yıllarında ekonomik yönden oldukça önemli kararlar içeren Milli Korunma Kanunu hakkında bilgiler verilmiştir. Yine ülkemizin eğitim alanında en önemli projelerinden biri olan Köy Enstitüleri konusuna değinilmiştir. Bir önceki bölümde değinilen Erzincan Depremi'nin yaratmış olduğu iç huzursuzluk konusu ele alınmıştır. Hemen ardından ise devam etmekte olan Avrupa Savaşı'nın gelişmeleri hakkında okuyucuya bilgiler verilmiştir.

Eserin üçüncü bölümünde 1941 yılında yaşanan gelişmelere yer verilmiş̧ir. Yazar savaş hakkında genel bir değerlendirme yaparak savaş hakkında meydana gelen olaylara değinmiştir. Bu değerlendirmelerden sonra Türkiye'nin Almanya ile yapmış olduğu Dostluk Paktı konusunda bilgiler vermiştir. Hemen ardından ise İkinci Dünya Savaşı'nın kırılma noktasını oluşturan ve Almanya'nın savaşı kaybetmesine kadar gidecek olan Rus topraklarını işgal etme planı olan Barbarossa Harekatı'na değinilmiştir. Yazar ayrıca savaşın Uzak doğudaki yansıması olan Pasifik Savaşı'na da yer vermiştir. Yazar bu bölümü Refah Vapurunda meydana gelen faciayı anlatarak noktalamıştır.

Eserin dördüncü bölümü 1942 yılında meydana gelen gelişmeleri içermektedir. Yazar ilk olarak savaşın ortalarına doğru kurulmuş olan Şükrü Saraçoğlu Hükümeti konusuna değinmiştir. Saraçoğlu Hükümeti'nin kurulmasının ardından ülkemiz ekonomik anlamda büyük sıkıntılar çekmeye devam etmiştir. Yazar bu bölümde ağırlıklı olarak ekonomik anlamda yaşanan sıkıntılara değinmiştir. Yine savaş döneminde kabul edilen Varlık Vergisi hakkında yazar bilgiler vermiştir.

Eserin beşinci bölümü 1943 yılına ayrılmıştır. Yazar savaş devam ederken toplanan Kazablanka Buluşmaları konusunda okuyuculara bilgiler vermiştir. Hemen 
ardından ise İngiltere'nin Türkiye'yi savaşa sokmak adına büyük fedakarlıklar göstermeye hazır olduğu Adana Görüşmeleri konusuna değinilmiştir. Bölümün devamında Yedinci T.B.M.M.'nin yapısı hakkında bilgiler verilmiştir. Meclisin kurulması hakkında bilgiler verilmesinin ardından Özalp Olayı ele alınmıştır. Bölümü oluşturan diğer başlıkları ise savaşın dış gelişmeleri oluşturmaktadır. Savaş devam ederken toplanan Moskova Konferansı, Kahire Buluşmaları ve Tahran Konferansı 1943 yılına damgasını vurmuştur. Yazar, sözü edilen konferansların içeriğine ve bu konferansların savaş açısından almış oldukları önemli kararlara değinmiştir.

Eserin altıncı bölümü 1944 yılında meydana gelen gelişmelere ayrılmıştır. Savaşın sonlarına doğru Türk-İngiliz ilişkilerinin genel durumu hakkında bilgiler verilmiştir. Diğer bir başlıkta ise 1925 yllında kaldırılan Aşar Vergisinin bir benzeri olan Toprak Mahsulleri Vergisi konusuna değinilmiştir. Yazarın bu bölümde değindiği farklı bir konu olarak karşımıza Irkçılık ve Turancılık çıkmaktadır. Yazarın değinmiş olduğu İkinci Dünya Savaşını Almanya'nın kaybetmesine neden olan ve Müttefik Devletlerin zaferi ile sonuçlanmış olan Normandiya Çıkarması 1944 yılının en önemli olaylarından birini oluşturmaktadır. Yine aynı yıl Normandiya Çıkarması devam ederken ülkemiz Almanya ile olan ilişkilerini kesme durumuna gelmiştir. Yazar 1944 yılında meydana gelen önemli gelişmelerin genel bir değerlendirmesini yaparak bölümü noktalamıştır.

Eserin son bölümünü savaşın bitiş yılı olan 1945 yılı meydana getirmektedir. Almanya ile ilişkilerin kesilmesinin ardından 1945 yılında Japonya ile de olan ilişkilerin kesilmesine değinilmiştir. Yazar Anayasa dilinin değiştirilmesi hakkındaki konuya değinerek okuyucuları bilgilendirmiştir. Bölümün devamında ise savaş yıllarındaki Devletçilik Anlayışı konusuna değinilmiştir. Yazar 1945 yılında toplanan Yalta Konferansına değinerek Türkiye'nin Almanya ve Japonya'ya karşı savaş ilan etmesi ile birlikte artık savaşın sonuna doğru gelindiğini göstermiştir. Bölümün bir diğer başlı̆̆ında ise 1945 Mayıs ayında savaşın Avrupa'da sona ermesi konusu ele alınmıştır. Yazar yine aynı yıl toplanan San Francisco ve Potsdam Konferansları ve alınan kararlara değinmiştir. Yazar savaşın sonlanmasıyla birlikte bu bölümde iç politikada meydana gelen olaylara da değinmiştir. Özellikle CHP'de yaşanan muhalefet hareketi sonucunda ortaya çıkan Dörtlü Önerge büyük bir önem taşımaktadır. Yazar bölümün sonunda ise İkinci Dünya Savaşı sonrasında Türkiye'de uzun zamandır oluşturulamayan Çok Partili Cumhuriyet konusuna değinmiştir.

Eser toplamda 7 ana bölüm ve bunların alt başlıklarından meydana gelmiştir. Yazar eserin sonuna ek olarak "Altıncı Dönem Türkiye Büyük Millet Meclisi Milletvekilleri Listesi (1939- 1943)", "Yedinci Dönem Türkiye Büyük Milletvekilleri Listesi (1943- 1946)" ve son olarak ise "Anavatana Katılan Hatay Devleti'nin Ulusal Meclis Üyelerinin Listesi”ni okuyucuya sunmuştur. Yine yazar eserinde "Kaynakça" ve "Dizin" bölümlerine de yer vermiştir. 
Eserde, meydana gelen olaylar kronolojik olarak okuyucuya sunulmuştur. Meydana gelen olaylar ayrıca okuyucuyu sıkmayacak sadelikte ve açıklayıcı bir anlatım tarzıyla kaleme alınmıştır. Yazarın zabıt ceridelerini kullanması da eser açısından oldukça faydalı olmuştur. Ayrıca eserde "Dizin" bölümünün olması da okuyucuların aradıkları konuyu bulmaları açısından avantaj sağlamaktadır. Yazar eserde yaşanan olaylar ile ilgili herhangi bir görsel unsur kullanmamayı tercih etmiştir. Yazarın esere görsellik katması açısından dönemin olaylarını yansıtan bir gazete veya dergiden fotoğraflar eklemesi faydalı olacaktır. Görsel öğelerin hiç kullanılmaması eserin eksik yönlerinden birisidir. Eser sadece savaş teması üzerine yazılmamıştır. Eserde iç ve dış gelişmeleri yansıtan olaylar iç içe verilmiştir. Böyle toplu bir anlatım tarzı yerine bu olayların kendi içerisinde bir tasnifi yapılarak okuyucuya sunulması daha uygun olacaktır. Yine eserin sayfa sayısının fazla olmasına rağmen yazarın kaynakçada kullandığı eser sayısı da beklenilen düzeyde olmamıştır. Eser, savaş tarihi anlatan diğer kaynaklara göre karmaşık ve gereksiz bilgilerden arındırılarak kaleme alınmıştır. Eser, İkinci Dünya Savaşı hakkında okuma veya araştırma yapmak isteyenler için içerisinde toplumsal, siyasi ve askeri konuları barındıran bir özelliğe sahiptir. 